Mariana Rydchuk, Teodoziya Vrublevska, Mariya Boiko and Olha Korkuna

\title{
İ ASKING IS THE EFFECTIVE ALTERNATIVE TO THE SEPARATION DURING OSMIUM DETERMINATION BY MEANS OF AZO DYES IN COMPLEX SAMPLES
}

\author{
Ivan Franko National University of Lviv, \\ Kyryla i M efodiya Str., 6, 79005, Lviv, Ukraine \\ marianne_polko@yahoo.com
}

Received: December 12, 2009

@ C Rydchuk M., Vrublevska T., Boyko M., Korkuna O., 2010

\begin{abstract}
The selectivity of the spectrophotometric methods for determination of microgram quantities of osmium (IV) with acidic monoazo dyes Tropaeolin O (TpO) and Tropaeolin OOO-I (TpOOOI) in the presence of concomitant metals, particularly platinum group, heavy and rare earths (RE) has been studied. The tolerance ratios of interfering elements have been established. The selectivity of the interaction of TpOOOI with osmium (IV) relatively to platinum group elements (PGEs) is much better than TpO. It has been established that the influence of interfering ions can be easily eliminated by means of masking agents viz. EDTA, tartrate, citrate, pyrophosphate and fluoride, and thereby the selectivity of the methods of osmium determination with $\mathrm{TpO}$ and $\mathrm{TpOOOI}$ has been sufficiently improved. The methods have been approved during the analyses of various model solutions containing ruthenium, platinum, palladium, rhodium and iridium and the masking reagents. Also osmium content has been determined in the intermetallic alloy $\mathrm{Nd}_{20} \mathrm{Os}_{15} \mathrm{Si}_{65}$. The standard deviations did not exceed typical values for spectrophotometric methods (RSDs $<5 \%$ ). Thus the elaborated methods with various masking agents may be used for direct determination of osmium in complex samples without any preliminary separation of osmium in the form of $\mathrm{OsO}_{4}$ as well as without the extraction of matrices elements.
\end{abstract}

Keywords: osmium, spectrophotometric determination, Tropaeolin O, Tropaeolin OOO-I, selectivity, masking, tolerance ratio of interfering ion.

\section{Introduction}

Osmium is the most expensive noble metal and it is one of the most dispersed elements of the Earth crust. Osmium does not occur in nature as a native metal, usually it is found in minerals (nevianskite, sisertskite, laurite) with iridium, meteorites and copper and nickel sulphide ores containing PGEs [1-4]. Osmium possesses unique physical and chemical properties, particularly refractoriness, exclusive hardness, corrosion and wear resistance $[1,2]$. Due to it osmium is widely used for the production of wearproof elements in electronic technology, measuring devices, clockworks. Volatile osmium tetraoxide is utilized as a catalyst of hydrogenation reactions in organic synthesis, for producing medicines and also as a developer for clinical histological researches [5]. Moreover, $\mathrm{OsO}_{4}$ even in minute quantities causes an allergy, irritates mucous membranes, affects skin, eyes and respiratory apparatus; has a harmful influence on heart and nervous system [6].

The control of osmium content in mineral raw materials, ores, industrial products, wastes of ores processing and concentration, jewellery manufacturing, waste materials of organic synthesis and medical and biological investigations is an important applied task of analytical chemistry. Also nowadays there is the necessity to analyze numerous industrial materials containing few components on the basis of PGEs in wide concentration ranges [2]. Spectrophotometry is an important tool for determination of noble metals in industrial and research laboratories. Main advantages of spectrophotometric techniques are simplicity, availability, rapid procedure of analyses and the ability to evaluate high as well as low concentrations of PGEs $[2,7,8]$. Most of generally used spectrophotometric methods of osmium determination demand rather complicated and prolonged procedures of osmium separation or concentration as well as different methods of matrix isolation, which may cause the serious error of analyses [1, 2, 7-9]. The ascertainment of osmium content in real samples is always complicated by the occurrence of few PGEs. The number of methods allowing the selective determination of osmium in the presence of noble metals is very small $[1,2,7-12]$, namely the spectrophotometric methods with tyron, bismuthol II, 
tetraphenylarsonium and tetraphenylphosphonium chlorides. Moreover, ions of alkali-earth and heavy metals, and also a number of anions which are brought in during the samples dissolving may hinder the analyses. The majority of known research works does not contain any experimental results concerning the selectivity of reactions, which are used for osmium evaluation in different samples [9]. Therefore the investigation dealing with the elaboration of new reliable, rapid and selective techniques for osmium determination in complex samples in the presence of other PGEs is an actual problem.

Azo dyes are awailable analytical reagents. We have firstly established that osmium (IV) forms coloured compounds with acidic monoazo dyes Tropaeolin $\mathrm{O}$ and Tropaeolin OOO-I (Fig. 1). Simple and sensitive methods for osmium determination have been elaborated on the basis of these reactions $[13,14]$.

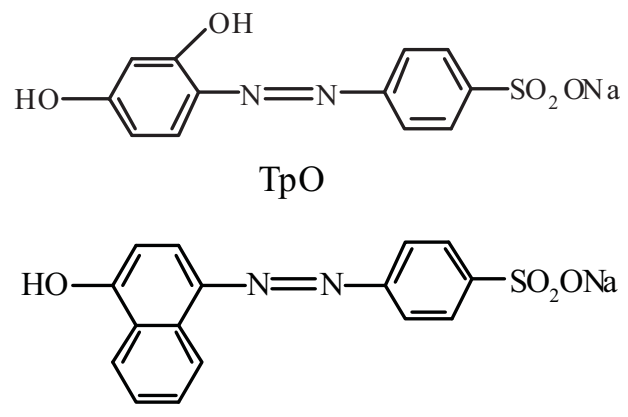

TpOOOI

Fig. 1. Structural formulas of the applied monoazo dyes

Tropaeolin O (Acid Orange 6, C.I. 14270) and Tropaeolin OOO-I (Acid Orange 20, C.I. 14600) are usually used as acid-base indicators: $\mathrm{TpO}$ at $\mathrm{pH}=11.0$ 13.0 changes its colour from yellow to reddish-brown $\left(\mathrm{pK}_{\mathrm{HL}}=11.8\right)[12,15]$, and the colour transition region for TpOOOI from orange to crimson-red is observed at $\mathrm{pH}=$ $7.4-8.9\left(\mathrm{pK}_{\mathrm{HL}}=8.2\right)[12,15-17]$. These dyes are applied for staining various fibres, leather and polymers into orange colour, as markers during microbiological researches and auxiliary substances for production of medicines. Practically there are no literature data concerning the spectrophotometric use of $\mathrm{TpO}$ and TpOOOI. There is only one photometric method for determination of $\mathrm{Pd}(\mathrm{II})$ with Tropaeolin $\mathrm{O}$ based on the formation of violet coloured complex compound $[18,19]$. It has been reported in Ref. [20-23] that Tropaeolin OOO-I is utilized for the extraction-photometric determination of fluoroquinolones in pharmaceutical formulations.

In this paper we present the results of the selectivity investigations of the elaborated spectrophotometric methods for Os(IV) determination with TpO and TpOOOI. Particularly we have studied how the presence of PGEs, heavy and RE metals and typical masking ions affect osmium (IV) evaluation by means of above mentioned azo reagents for the further elaboration of new selective and sensitive spectrophotometric techniques for the determination of this noble metal in complex samples.

\section{Experimental}

\subsection{Reagents}

All aqueous solutions were prepared using distilled water.

The solutions of all reagents were prepared from the chemicals of the analytical grade.

Stock solution of osmium (IV) $\left(\mathrm{H}_{2} \mathrm{OsCl}_{6}\right)$ was prepared by dissolving the exact mass of $\mathrm{OsO}_{4}$ (analytical grade) from a hermetically sealed glass ampoule in the concentrated hydrochloric acid, following the modified method [24]. The obtained osmium solution was stored for 1 month for the complete transferring of Os(VIII) into $\mathrm{Os}(\mathrm{IV})$, because $\mathrm{OsO}_{4}$ is rapidly reduced to $\mathrm{OsCl}_{6}{ }^{2-}$ on heating and slowly reduced at room temperature [25]. Standard working solutions of Os(IV) were prepared by dissolving an aliquot of Os(IV) initial stock solution in $c a$. $0.5-1 \mathrm{~mol} \cdot \mathrm{l}^{-1} \mathrm{HCl}$ aqueous solution up to $\mathrm{pH}<1$. According to Ref. [2], $\mathrm{OsCl}_{6}^{2-}$ does not undergo hydrolysis under room temperature in the media of hydrochloric acid, when $\mathrm{C}_{\mathrm{HCl}}>0.5 \mathrm{~mol} \cdot \mathrm{l}^{-1}$.

Solutions of Tropaeolin O ("Synbias", Ukraine) and Tropaeolin OOO-I (Shostkinskiy Chemical Plant, Ukraine) were prepared by dissolving appropriate amounts of the reagents in distilled water.

The solutions of $\mathrm{Cu}(\mathrm{II}), \mathrm{Ni}(\mathrm{II}), \mathrm{Co}(\mathrm{III}), \mathrm{Mg}(\mathrm{II})$, $\mathrm{Pb}(\mathrm{II}), \mathrm{Zn}(\mathrm{II}), \mathrm{Cd}(\mathrm{II}), \mathrm{Fe}(\mathrm{III}), \mathrm{Al}(\mathrm{III}), \mathrm{Ho}(\mathrm{III}), \mathrm{Tb}(\mathrm{III})$, $\mathrm{Nd}(\mathrm{III}), \mathrm{Ga}(\mathrm{III}), \mathrm{Sm}(\mathrm{III}), \mathrm{Eu}(\mathrm{III}), \mathrm{Ce}(\mathrm{IV}), \mathrm{Ag}(\mathrm{I})$ and Pd(II)were prepared by dissolving the exact mass of a metal $(99.99 \%)$ in nitric acid (1:1), and the solutions of $\mathrm{Au}(\mathrm{III})$ and $\mathrm{Pt}(\mathrm{IV})$ - by dissolving the exact mass of a metal $(99.99 \%)$ in the mixture of nitric $(1: 1)$ and hydrochloric $(1: 1)$ acids. To obtain chloride solutions of $\mathrm{Rh}(\mathrm{III})$ and $\mathrm{Ir}(\mathrm{IV})$ the sintering of metallic rhodium and iridium $(99.99 \%)$ with the oxidizing mixture of $\mathrm{NaNO}_{3}+\mathrm{NaOH}(1: 3)$ in the presence of barium peroxide on heating was carried out with the further dissolution of fusion cake in $\mathrm{HCl}$ following the method described in Ref. [26]. To obtain perchloric solutions of Ru(IV) the sintering of metallic ruthenium (99.99\%) with the oxidizing mixture $\mathrm{NaNO}_{3}+\mathrm{NaOH}(1: 3)$ was carried out with the further dissolution of fusion cake in $\mathrm{HClO}_{4}$ [26].

\subsection{Apparatus}

UV-VIS absorbance measurements were performed on a UV-VIS scanning spectrophotometer CARY.WIN UV-VIS-50 (Varian, USA) and photometer KFK-2 - UHL 4.2 (Zagorskiy Mechanical-Optical Plant, Russia) using 
$1-5 \mathrm{~cm}$ cuvettes. All absorbance measurements were performed at $c a .293 \mathrm{~K}$. pH measurements were carried out by a $\mathrm{pH}$-meter, model $\mathrm{pH}-150 \mathrm{M}$ (Gomelskiy Plant of Measuring Devices, Belarus), with a saturated silver chloride reference electrode. $\mathrm{pH}$ of each solution was adjusted using diluted $\mathrm{HCl}$ and $\mathrm{NaOH}$ solutions.

\subsection{Standardization of Osmium (IV) Solutions}

Due to possible osmium loss during the process of volatile $\mathrm{OsO}_{4}$ reduction to $\mathrm{OsCl}_{6}^{2-}$, a standardization of the obtained stock solution of $\mathrm{OsCl}_{6}^{2-}$ was carried out titrimetrically using $\mathrm{KI}$ as a reagent. The generated $\mathrm{I}_{2}$ was titrated by standardized $\mathrm{Na}_{2} \mathrm{~S}_{2} \mathrm{O}_{3}$ :

$$
\begin{gathered}
2 \mathrm{Os}^{4+}+2 \mathrm{I}^{-}(\text {excess }) \rightarrow 2 \mathrm{Os}^{3+}+\mathrm{I}_{2} \\
\mathrm{I}_{2}+2 \mathrm{~S}_{2} \mathrm{O}_{3}^{2-} \rightarrow 2 \mathrm{I}^{-}+\mathrm{S}_{4} \mathrm{O}_{6}^{2-}
\end{gathered}
$$

The identification of osmium (IV) solutions was carried out spectrophotometrically by comparing the recorded electronic absorption spectra (Fig. 2) with the literature data $[27,28]$.

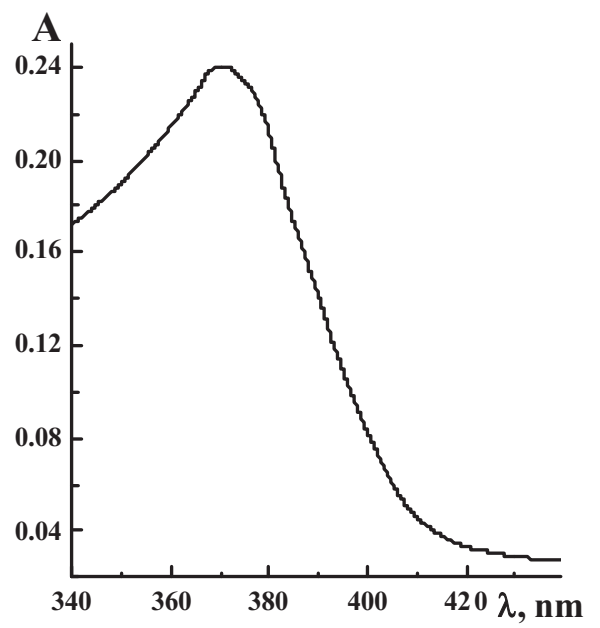

Fig. 2. Absorption spectrum of $\mathrm{OsCl}_{6}^{2-}$ solution; $\mathrm{C}_{\mathrm{Os}(\mathrm{IV})}=3.8 \cdot 10^{-3} \mathrm{~mol} \cdot \mathrm{l}^{-1}, \mathrm{C}_{\mathrm{HCl}}=1.0 \mathrm{~mol} \cdot \mathrm{l}^{-1}$

As follows from Fig. 2, the absorbance maximum is observed at $370 \mathrm{~nm}$, which corresponds to $\mathrm{OsCl}_{6}^{2-}$.

Hence, the initial $\mathrm{OsO}_{4}$ was quantitatively transformed to $\mathrm{OsCl}_{6}^{2-}$.

\subsection{Procedure of Determination of Osmium (IV) with Tropaeolin 0}

Consecutively $5.0 \mathrm{ml}$ of $1.25 \mathrm{~mol} \cdot \mathrm{l}^{-1}$ acetate buffer solution (sodium acetate - acetic acid) with $\mathrm{pH}=5.2$ and $5.0 \mathrm{ml}$ of $7.5 \cdot 10^{-4} \mathrm{~mol} \cdot 1^{-1} \mathrm{TpO}$ solution were placed into a $25 \mathrm{ml}$ volumetric flask. Then a sample of the solution containing $0.6-29.0 \mu \mathrm{g} \mathrm{ml}^{-1}$ of Os(IV) in the final volume was added. After that if necessary, the proper volume of the masking agent was added. $\mathrm{pH}$ value was adjusted to $\mathrm{pH}=5.2$ and distilled water was added to the full volume of $25 \mathrm{ml}$. The obtained solutions were heated on a boiling water bath $(c a .371 \mathrm{~K})$ for 10 minutes. Then solutions were cooled to $c a .293 \mathrm{~K}$. After cooling the absorbance measurements were carried out at $540 \mathrm{~nm}$ in $5.0 \mathrm{~cm}$ cuvettes vs. a blank solution. Osmium (IV) concentration was calculated using methods of the calibration curve or standard additions.

\subsection{Procedure of Determination of Osmium (IV) with Tropaeolin 000-I}

Consecutively $2.5 \mathrm{ml}$ of $0.1 \mathrm{~mol} \cdot \mathrm{1}^{-1}$ sodium tetraborate solution and $2.5 \mathrm{ml}$ of $7.5 \cdot 10^{-4} \mathrm{~mol} \cdot \mathrm{l}^{-1} \mathrm{TpOOOI}$ solution were placed into a $25 \mathrm{ml}$ volumetric flask. Then a sample of solution containing $0.01-1.15 \mu \mathrm{g} \cdot \mathrm{ml}^{-1}$ of Os(IV) in the final volume was added. After that if necessary, the proper volume of the masking agent was brought in. $\mathrm{pH}$ value was adjusted to $\mathrm{pH}=8.0$ and distilled water was added to the full volume of $25 \mathrm{ml}$. The obtained solutions were heated on a boiling water bath $(c a .371 \mathrm{~K})$ for 30 minutes. Then solutions were cooled to $c a$. $293 \mathrm{~K}$. After cooling the absorbance measurements were carried out at $364 \mathrm{~nm}$ in $5.0 \mathrm{~cm}$ cuvettes $v s$. a blank solution. Osmium (IV) concentration was calculated using methods of the calibration curve or standard additions.

\section{Results and Discussion}

\subsection{Electronic Absorbance Spectra of Osmium (IV) Compounds with TpO and TpOOOI}

The ions of Os(IV) form dark-orange coloured complex compound with Tropaeolin $\mathrm{O}$ in a weakly acidic media [13]. As seen from the electronic absorption spectra (Fig. 3), the maximum absorbance signal of a dye appeared at $393 \mathrm{~nm}$. For the complex Os(IV)-TpO maximum absorbance is observed in the same spectral range. However the absorbance shoulder at $\lambda=475-600 \mathrm{~nm}$ was also exhibited on the complex spectrum. The wavelength of $540 \mathrm{~nm}$ was used for investigations, where the maximum difference between the absorbance of the reagent and the product of TpO reaction with Os(IV) was observed and where the absorbance of azo dye was minute.

Orange-brown coloured compound of Os(IV) with TpOOOI is formed in the weakly alkaline media [14]. The locations of absorbance maxima of the complex and the dye practically coincide (Fig. 4), thus for absorbance measurements the wavelength of $364 \mathrm{~nm}$ was used, which is in the range of the wide absorbance shoulder at $\lambda<400 \mathrm{~nm}$, where the absorbance of the compound is much higher than the one for Tropaeolin OOO-I. 


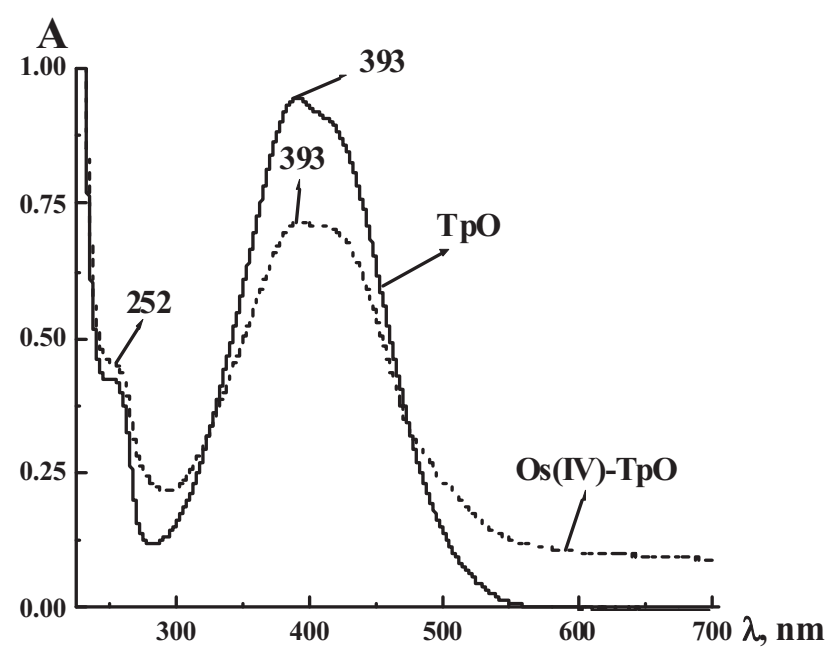

Fig. 3. Absorption spectra of Tropaeolin $\mathrm{O}$ and $\mathrm{Os}(\mathrm{IV})-\mathrm{TpO}$ compound; $\mathrm{C}_{\mathrm{Os}(\mathrm{IV})}=3.0 \cdot 10^{-5} \mathrm{~mol} \cdot \mathrm{l}^{-1} ; \mathrm{C}_{\mathrm{TpO}}=4.5 \cdot 10^{-5} \mathrm{~mol} \cdot \mathrm{l}^{-1}$; $\mathrm{C}\left(\mathrm{CH}_{3} \mathrm{COONa}+\mathrm{CH}_{3} \mathrm{COOH}\right)=0.3 \mathrm{~mol} \cdot \cdot^{-1} ; \mathrm{pH}=5.2 ; 1=1 \mathrm{~cm}$

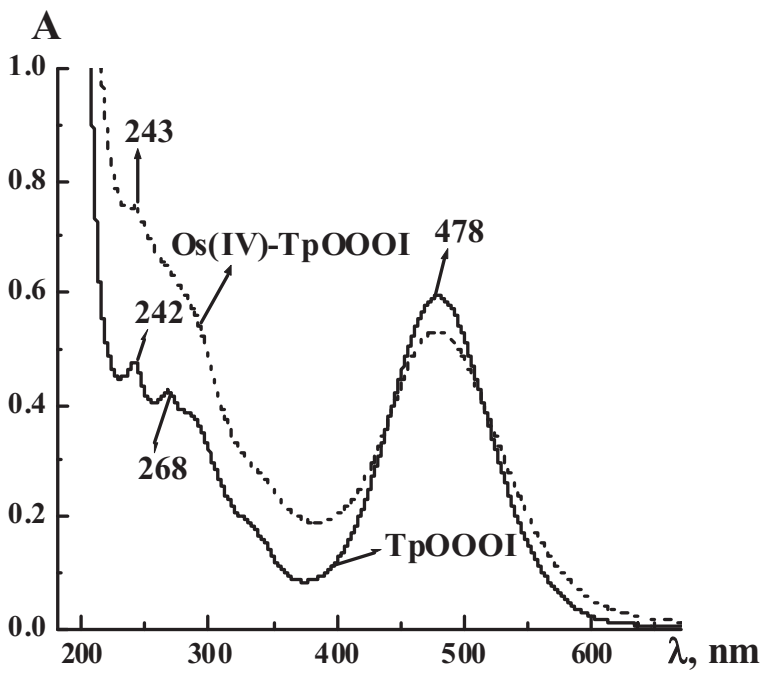

Fig. 4. Absorption spectra of Tropaeolin OOO-I and Os(IV)-TpOOOI compound; $\mathrm{C}_{\mathrm{Os}(\mathrm{IV})}=7.5 \cdot 10^{-6} \mathrm{~mol} \cdot \mathrm{l}^{-1} ; \mathrm{C}_{\text {TpOoOI }}=3.0 \cdot 10^{-5} \mathrm{~mol} \cdot \mathrm{l}^{-1}$; $\mathrm{C}\left(\mathrm{Na}_{2} \mathrm{~B}_{4} \mathrm{O}_{7}\right)=0.05 \mathrm{~mol} \cdot \mathrm{l}^{-1} ; \mathrm{pH}=8.0 ; 1=1 \mathrm{~cm}$

\subsection{Optimal Conditions of Osmium (IV) Coloured Complex Compounds Formation}

Osmium (IV) complex compounds with Tropaeolin O and Tropaeolin OOO-I are formed in sufficiently wide range of media acidity in the presence of many sodium salts, such as chloride, nitrate, sulphate. To maintain a constant ionic strength in the systems Os(IV)-TpO and Os(IV)-TpOOOI acetate buffer (sodium acetate-acetic acid) and sodium tetraborate solutions were utilized respectively. The presence of these substances provides the stable conditions for complexation and sufficiently improves the rapidity of the procedures of osmium determination.
The coloured compounds of Os(IV) with the investigated acidic monoazo dyes practically are not formed at room temperature. To obtain the complexes the solutions must be heated on a boiling water bath ( $c a .371 \mathrm{~K}$ ) for the partial overcoming of the substantial kinetic inertness of initial $\mathrm{OsCl}_{6}{ }^{2-}$. When the solutions of analytes, obtained after the proper heating procedure, are kept in time, the absorbance values are stable more than $24 \mathrm{~h}$, moreover after that time the absorbance is still slightly increasing.

The maximum yield of Os(IV)-TpO compound as well as of Os(IV)-TpOOOI complex is observed when aliquots of buffer solution, reagent and osmium (IV) solutions are sequentially added into a volumetric flask, $\mathrm{pH}$ value of the media is adjusted using solutions of hydrochloric acid and sodium hydroxide and the mixture is heated on a boiling water bath.

The components ratios in the studied systems of Os(IV) with azo dyes were established by means of mole ratio and Job's method of continuous variations. Using the experimental data obtained by these methods the values of effective molar absorptivities of Os(IV) complexes with azo reagents and optimal excesses of the reagents were calculated.

The optimal conditions of the formation of osmium (IV) coloured compounds with Tropaeolin $\mathrm{O}$ and Tropaeolin OOO-I and some characteristics of these complexes are summarized in Table 1.

\subsection{Sensitivity and Linear Range of the Spectrophotometric Determination of Os(IV) with Tropaeolin 0 and Tropaeolin 000-I}

The values of analytical signals linearly depend on the concentration of the analyte in the solution during the spectrophotometric determination of Os(IV) with TpO and TpOOOI. The validation results of the elaborated methods are presented in Table 2.

Thus the elaborated methods for the spectrophotometric determination of osmium (IV) with TpO and TpOOOI possess wide linear ranges; they are simple, rapid and sensitive. Especially sensitive is the reaction of Os(IV) with Tropaeolin OOO-I, which is more sensitive than the most known spectrophotometric methods of osmium determination [1].

\subsection{Influence of Extraneous Ions}

Osmium is mainly evaluated in complex samples in the presence of other metals, particularly PGEs, which possess similar chemical and analytical properties. Therefore the investigation of the influence of extraneous ions to achieve the selectivity of the spectrophotometric reaction is an important task when a new technique is elaborated. That is why we have studied the influence of 
The optimal conditions of the formation and some characteristics

Table 1 of osmium (IV) coloured complex compounds with acidic monoazo dyes Tropaeolin O and Tropaeolin OOO-I

\begin{tabular}{|c|c|c|}
\hline Reagent & Tropaeolin O & Tropaeolin OOO-I \\
\hline$\lambda, \mathrm{nm}$ & 540 & 364 \\
\hline$\varepsilon_{\lambda} \cdot 10^{-4}, 1 \mathrm{~mol}^{-1} \mathrm{~cm}^{-1}$ & 0.2 & 2.3 \\
\hline $\mathrm{pH}$ & 5.2 & 8.0 \\
\hline Buffer solution & $0.3 \mathrm{M}\left(\mathrm{CH}_{3} \mathrm{COOH}+\mathrm{CH}_{3} \mathrm{COONa}\right)$ & $0.05 \mathrm{M} \mathrm{Na}_{2} \mathrm{~B}_{4} \mathrm{O}_{7}$ \\
\hline Reagents excess & 1.5 -fold & 12-fold \\
\hline Order of reagents adding & \multicolumn{2}{|c|}{$[($ Buffer solution + Reagent $+\mathrm{Os}(\mathrm{IV})) \mathrm{pH}] \mathrm{t}_{\text {heating }}$} \\
\hline Time of heating, min & 10 & 30 \\
\hline Time of complex stability, $\mathrm{h}$ & 25 & $>30$ \\
\hline Os : reagent ratio & $3: 2$ & $1: 4$ \\
\hline
\end{tabular}

The validation results of osmium (IV) spectrophotometric determination with Tropaeolin $\mathrm{O}\left(\mathrm{C}_{\mathrm{TpO}}=3.0 \cdot 10^{-4} \mathrm{~mol} \cdot \mathrm{I}^{-1} ; \mathrm{C}\left(\mathrm{CH}_{3} \mathrm{COONa}+\mathrm{CH}_{3} \mathrm{COOH}\right)=0.3 \mathrm{~mol} \cdot \mathrm{I}^{-1} ; \mathrm{pH}=5.2 ; \lambda=540 \mathrm{~nm}\right)$ and Tropaeolin OOO-I $\left(\mathrm{C}_{\mathrm{Tp} \text { Oool }}=7.8 \cdot 10^{-5} \mathrm{~mol} \cdot \mathrm{I}^{-1} ; \mathrm{C}\left(\mathrm{Na}_{2} \mathrm{~B}_{4} \mathrm{O}_{7}\right)=0.05 \mathrm{~mol} \cdot \mathrm{l}^{-1} ; \mathrm{pH}=8.0 ; \lambda=364 \mathrm{~nm}\right)$. $l=5 \mathrm{~cm} ; n=5 ; P=0.95$

\begin{tabular}{|c|c|c|c|c|c|}
\hline System & $\begin{array}{c}\text { Linear range } \\
C_{O S}, \mu \mathrm{g} \mathrm{ml} l^{-1}\end{array}$ & $\begin{array}{c}\text { Regression equation of } \\
\text { calibration plot, } \\
C_{O s}, \mu \mathrm{g} \mathrm{m} l^{-1}\end{array}$ & $\begin{array}{c}\text { Limit of } \\
\text { Quantification, } \\
\mu \mathrm{g} \mathrm{ml}^{-1}\end{array}$ & $\begin{array}{c}\text { Sandell's } \\
\text { sensitivity } \\
m_{S}, \mu \mathrm{g} / \mathrm{cm}^{2}\end{array}$ & $\begin{array}{c}\text { Correlation } \\
\text { coefficient, } R\end{array}$ \\
\hline Os(IV)-TpO & $0.6-28.7$ & $\Delta \mathrm{A}=0.034+0.037 \times \mathrm{C}_{\mathrm{Os}}$ & 0.3 & 0.27 & 0.9994 \\
\hline \multirow{2}{*}{ Os(IV)-TpOOOI } & $0.005-0.070$ & $\Delta \mathrm{A}=0.044+5.718 \times \mathrm{C}_{\mathrm{Os}}$ & 0.002 & 0.008 & 0.9998 \\
\cline { 2 - 3 } & $0.07-1.15$ & $\Delta \mathrm{A}=0.418+0.240 \times \mathrm{C}_{\mathrm{Os}}$ & & 0.9981 \\
\hline
\end{tabular}

Table 3

Tolerance ratios of extraneous ions during the spectrophotometric determination of Os(IV) with TpO $\left(\mathrm{C}_{\mathrm{Os}(\mathrm{IVV}}=6.0 \cdot 10^{-5} \mathrm{~mol} \cdot \mathrm{l}^{-1} ; \mathrm{C}_{\mathrm{TpO}}=1.2 \cdot 10^{-4} \mathrm{~mol} \cdot \mathrm{l}^{-1} ; \mathrm{C}\left(\mathrm{CH}_{3} \mathrm{COONa}+\mathrm{CH}_{3} \mathrm{COOH}\right)=0.3 \mathrm{~mol} \cdot \mathrm{l}^{-1} ; \mathrm{pH}=5.2\right.$; $\lambda=540 \mathrm{~nm} ; l=5 \mathrm{~cm})$ and TpOOOI $\left(\mathrm{C}_{\mathrm{Os}(\mathrm{VV})}=4.5 \cdot 10^{-6} \mathrm{~mol} \cdot \mathrm{I}^{-1} ; \mathrm{C}_{\mathrm{TpOooI}}=5.4 \cdot 10^{-5} \mathrm{~mol} \cdot \mathrm{I}^{-1}\right.$; $\left.\mathrm{C}\left(\mathrm{Na}_{2} \mathrm{~B}_{4} \mathrm{O}_{7}\right)=0.05 \mathrm{~mol} \cdot \mathrm{l}^{-1} ; \mathrm{pH}=8.0 ; \lambda=364 \mathrm{~nm} ; l=3 \mathrm{~cm}\right)$

\begin{tabular}{|c|c|c|c|c|c|c|c|c|}
\hline \multirow{2}{*}{ Ion } & \multicolumn{2}{|c|}{$\mathrm{C}_{\mathrm{OS}}: \mathrm{C}_{\text {Ion }}$} & \multirow{2}{*}{ Ion } & \multicolumn{2}{|c|}{$\mathrm{C}_{\mathrm{OS}}: \mathrm{C}_{\text {Ion }}$} & \multirow{2}{*}{ Ion } & \multicolumn{2}{|c|}{$\mathrm{C}_{\mathrm{OS}}: \mathrm{C}_{\text {Ion }}$} \\
\hline & $\mathrm{TpO}$ & TpOOOI & & $\mathrm{TpO}$ & TpOOOI & & TpO & TpOOOI \\
\hline $\mathrm{Ru}(\mathrm{IV})$ & $1: 0.1$ & $1: 5$ & $\mathrm{Zn}(\mathrm{II})$ & $1: 150$ & $1: 5$ & $\mathrm{Al}(\mathrm{III})$ & $1: 7$ & $1: 3$ \\
\hline $\mathrm{Rh}(\mathrm{III})$ & $1:<0.1$ & $1: 2$ & $\mathrm{~Pb}(\mathrm{II})$ & $1: 5$ & $1: 1$ & $\mathrm{Ca}(\mathrm{II})$ & $1: 1000^{*}$ & $1: 1000^{*}$ \\
\hline $\operatorname{Pd}(\mathrm{II})$ & $1:<0.1$ & $1: 5$ & Gd(III) & $1: 3$ & $1: 1$ & $\mathrm{Mg}(\mathrm{II})$ & $1: 1000^{*}$ & $1: 1000^{*}$ \\
\hline $\mathrm{Pt}(\mathrm{IV})$ & 1:0.1 & $1: 1$ & $\mathrm{~Tb}(\mathrm{III})$ & $1: 150$ & $1: 50$ & & & \\
\hline $\operatorname{Ir}(\mathrm{IV})$ & $1: 0.2$ & $1: 3$ & Ho(III) & $1: 80$ & $1: 5$ & $\mathrm{~S}_{2} \mathrm{O}_{3}{ }^{2-}$ & $1: 3$ & $1: 20$ \\
\hline $\mathrm{Cu}(\mathrm{II})$ & $1: 0.1$ & $1: 3$ & $\mathrm{Sm}(\mathrm{III})$ & $1: 3$ & $1: 20$ & $\mathrm{~F}^{-}$ & $1: 500^{*}$ & $1: 500^{*}$ \\
\hline $\operatorname{Ag}(\mathrm{I})$ & $1: 3$ & $1: 20$ & $\mathrm{Ce}(\mathrm{IV})$ & $1: 2$ & $1: 2$ & $\mathrm{P}_{2} \mathrm{O}_{7}^{4-}$ & $1: 400$ & $1: 100$ \\
\hline $\mathrm{Au}(\mathrm{III})$ & $1: 0.1$ & $1: 2$ & $\mathrm{Ce}(\mathrm{III})$ & $1: 30$ & $1: 2$ & ЕДТА & $1: 30$ & $1: 60$ \\
\hline $\mathrm{Ni}(\mathrm{II})$ & $1: 40$ & $1: 1$ & $\mathrm{Nd}(\mathrm{III})$ & $1: 100$ & $1: 40$ & $\mathrm{Cit}^{3-}$ & $1: 10$ & $1: 100$ \\
\hline $\mathrm{Co}(\mathrm{III})$ & $1: 80$ & $1: 5$ & $\mathrm{Eu}(\mathrm{III})$ & $1: 30$ & $1: 10$ & Tart $^{2-}$ & $1: 40$ & $1: 30$ \\
\hline $\mathrm{Cd}(\mathrm{II})$ & $1: 20$ & $1: 300$ & $\mathrm{Fe}(\mathrm{III})$ & $1: 0.8$ & $1: 3$ & $\mathrm{SiO}_{3}{ }^{2-}$ & $1: 100$ & $1: 100$ \\
\hline
\end{tabular}

* - higher concentrations of marked ions were not investigated 
the occurrence of some metals ions including PGEs and typical masking anions (EDTA, fluoride, citrate, tartrate, thiosulphate and pyrophosphate) on the possibility of osmium (IV) determination with Tropaeolin $\mathrm{O}$ and Tropaeolin OOO-I. Also the effect of rare earth elements and silicate-ions was investigated, since one of the samples, during the analysis of which we approved the elaborated methods, were intermetallic alloys of three components: silicium, RE and osmium.

The interfering influence of extraneous ions was tested to that concentration (molar) tolerance ratio Os(IV):Ion, when the deviation of the absorbance value in the presence of interferent exceeded $10 \%$ of the absorbance of Os(IV) solution without any foreign ions [29].

The results of the selectivity investigations of osmium (IV) spectrophotometric determination with Tropaeolin O and Tropaeolin OOO-I are given in Table 3.

According to the experimental results the complex compound $\mathrm{Os}(\mathrm{IV})-\mathrm{TpO}$ is formed in the presence of great excesses of $\mathrm{Ca}(\mathrm{II}), \mathrm{Mg}$ (II), $\mathrm{Ni}(\mathrm{II}), \mathrm{Co}$ (III), $\mathrm{Zn}$ (II), $\mathrm{Cd}(\mathrm{II})$ $\left(\mathrm{C}_{\mathrm{O}}: \mathrm{C}_{\mathrm{Ion}} \geq \square 1: 20\right)$, some RE, though the commensurable concentrations of iron (III), aluminium (III), silver (I) and lead (II) and the small quantities of PGEs, copper (II) and aurum (III) $\left(\mathrm{C}_{\mathrm{Os}}: \mathrm{C}_{\text {Ion }} \leq \square 1: 0.1\right)$ interfere. It has been established that thiosulphate and sufficient excesses of organic anions hinder the complexation of Os(IV) with Tropaeolin $\mathrm{O}$, and fluoride- and pyrophosphate-ions practically do not affect.

Great excesses of $\mathrm{Ca}(\mathrm{II}), \mathrm{Mg}(\mathrm{II}), \mathrm{Cd}(\mathrm{II}), \mathrm{Ag}(\mathrm{I})$, $\mathrm{Nd}(\mathrm{III}), \mathrm{Tb}(\mathrm{III}), \mathrm{Sm}(\mathrm{III})\left(\mathrm{C}_{\mathrm{Os}}: \mathrm{C}_{\mathrm{Ion}} \geq \square 1: 20\right)$ and commensurable quantities of PGEs, $\mathrm{Au}(\mathrm{III}), \mathrm{Cu}(\mathrm{II})$, some $\mathrm{RE}$, heavy metals, $\mathrm{Fe}(\mathrm{III})$ and $\mathrm{Al}(\mathrm{III})$ do not interfere determination of Os(IV) with TpOOOI. The compound of osmium with Tropaeolin OOO-I is formed in the occurrence of the considerable amounts of citrate, pyrophosphate, tartrate and EDTA. Fluoride-ion does not effect the interaction of osmium and reagent.

Hence, TpOOOI appears to be sufficiently more selective than TpO, interacting with Os(IV) in the presence of PGEs ions. It may be caused by the fact that weakly alkaline media is the optimal one to obtain the coloured product Os(IV)-TpOOOI, whereas weakly acidic media is necessary for the maximum yield of $\mathrm{Os}(\mathrm{IV})-\mathrm{TpO}$ complex. Thus at $\mathrm{pH}=8.0$ the greater part of noble metals ions than at $\mathrm{pH}=5.2$ exists in the form of substituted hydroxocomplexes, which probably are more stable than the compounds of extraneous PGEs with azo reagents. On the other hand, Tropaeolin O differs from Tropaeolin OOO-I with the position of $\mathrm{OH}$-group relatively to azo group, which may also cause the different selectivity of the reagents in the presence of PGEs due to various steric hindrance. Therefore, $\mathrm{TpO}$ may be utilized for the direct spectrophotometric determination of osmium (IV) in the samples of few components containing heavy and RE metals, and TpOOOI - in the samples containing commensurable quantities of noble metals.
The results concerning the effect of typical masking agents on determination of Os(IV) with acidic monoazo dyes indicate that these substances can be applied to eliminate the interfering influence of the ions of extraneous metals.

\subsection{Masking of Interfering Extraneous Ions}

Usually the interfering influence of extraneous ions is eliminated by means of the complexation reactions with typical masking agents, and mostly it comes to binding a foreign element into the colourless complex. In other words, after adding of a masking agent into a solution the compound of an extraneous metal with an analytical reagent is not formed, whereas the coloured compound of the analyte remains unchanged [29].

To improve the selectivity of the reactions of $\mathrm{TpO}$ and TpOOOI with osmium (IV) the maximum permissible excesses of the masking reagents relatively to osmium were used to bind the interferent as much as possible.

Table 4 presents the results of masking some interfering ions using EDTA, tartrate, fluoride and pyrophosphate during the spectrophotometric determination of osmium (IV) with Tropaeolin O.

According to data from Table 4, pyrophosphate masked high concentrations of iron (III) and aluminium (III) and commensurable concentrations of copper (II), ruthenium (IV), rhodium (III), platinum (IV) and iridium (IV). EDTA masked comparable quantities of PGEs and Fe(III), tartrate - great excesses of $\mathrm{Al}(\mathrm{III})$ and $\mathrm{Fe}(\mathrm{III})$ as well as ruthenium (IV), platinum (IV), rhodium (III) and iridium (IV); fluoride eliminated the influence of very large amounts of aluminium (III), and EDTA - the commensurable concentrations of iron (III) and PGEs, including Pd(II), which greatly interferes, since it forms with $\mathrm{TpO}$ a violet coloured compound [18, 19].

The results of masking the interfering ions by means of EDTA, citrate, tartrate and fluoride during the spectrophotometric determination of osmium (IV) with Tropaeolin OOO-I are presented in Table 5.

As follows from Table 5, EDTA masked great excesses of $\mathrm{Al}(\mathrm{III}), \mathrm{Zn}(\mathrm{II}), \mathrm{Ni}(\mathrm{II}), \mathrm{Rh}(\mathrm{III}), \mathrm{Ru}(\mathrm{IV}), \mathrm{Ir}(\mathrm{IV})$, and comparable quantities of RE, $\mathrm{Cu}(\mathrm{II})$ and $\mathrm{Pt}(\mathrm{IV})$, and citrate - large excesses of Pt(IV), Ru(IV), Ir(IV), Zn(II) and $\mathrm{Al}(\mathrm{III})$ and commensurable amounts of iron (III), nickel (II), aurum (III) and rhodium (III). By means of tartrate we succeeded in the effects elimination of the great excesses of Al(III), $\mathrm{Ni}(\mathrm{II}), \mathrm{Cu}$ (II) and comparable quantities of rhodium (III) and iridium (IV), and by means of fluoride - sufficient quantities of aluminium (III) and commensurable concentrations of rhodium(III), iridium (IV) and platinum (IV).

Hence, the examined masking reagent are useful for elimination of the interfering influence of many 
Table 4

Tolerance ratios of interfering ions during the spectrophotometric determination of osmium (IV) with Tropaeolin $\mathrm{O}\left(\mathrm{C}_{\mathrm{Os}(\mathrm{IV})}=6.0 \cdot 10^{-5} \mathrm{~mol} \cdot \mathrm{l}^{-1} ; \mathrm{C}_{\mathrm{TpO}}=1.2 \cdot 10^{-4} \mathrm{~mol} \cdot \mathrm{l}^{-1} ; \mathrm{C}\left(\mathrm{CH}_{3} \mathrm{COONa}+\mathrm{CH}_{3} \mathrm{COOH}\right)=0.3 \mathrm{~mol} \cdot \mathrm{l}^{-1}\right.$; $\mathrm{pH}=5.2 ; \lambda=540 \mathrm{~nm} ; l=5 \mathrm{~cm})$ using masking agents

\begin{tabular}{|c|c|c|c|c|}
\hline \multirow{2}{*}{ Extraneous ion } & \multicolumn{4}{|c|}{ Masking agent $\left(\mathrm{C}_{\mathrm{Os}}: \mathrm{C}_{\text {Ion }}: \mathrm{C}_{\text {Masking agent }}\right)$} \\
\cline { 2 - 5 } & EDTA & Tart $^{2-}$ & $\mathrm{F}^{-}$ & $\mathrm{P}_{2} \mathrm{O}_{7}{ }^{4-}$ \\
\hline $\mathrm{Fe}(\mathrm{III})$ & $1: 5: 30$ & $1: 25: 40$ & - & $1: 40: 400$ \\
\hline $\mathrm{Al}(\mathrm{III})$ & - & $1: 200: 40$ & $1: 600: 500$ & $1: 100: 400$ \\
\hline $\mathrm{Cu}(\mathrm{II})$ & - & - & - & $1: 1: 400$ \\
\hline $\mathrm{Ce}(\mathrm{IV})$ & - & - & $1: 8: 500$ & - \\
\hline $\mathrm{Gd}(\mathrm{III})$ & $1: 7: 30$ & $1: 5: 40$ & - & - \\
\hline $\mathrm{Ru}(\mathrm{IV})$ & $1: 0.5: 30$ & $1: 2: 40$ & - & $1: 2: 400$ \\
\hline $\mathrm{Rh}(\mathrm{III})$ & $1: 2: 30$ & $1: 0.3: 40$ & - & $1: 2: 400$ \\
\hline $\mathrm{Pd}(\mathrm{II})$ & $1: 1: 30$ & - & - & - \\
\hline $\mathrm{Pt}(\mathrm{IV})$ & $1: 5: 30$ & $1: 5: 40$ & $1: 0.5: 500$ & $1: 0.5: 400$ \\
\hline $\mathrm{Ir}(\mathrm{IV})$ & $1: 4: 30$ & $1: 2: 40$ & - & $1: 6: 400$ \\
\hline
\end{tabular}

— no masking effect detected

Table 5

Tolerance ratios of interfering ions during the spectrophotometric determination of osmium (IV) with Tropaeolin OOO-I $\left(\mathrm{C}_{\mathrm{Os}(\mathrm{IV})}=4.5 \cdot 10^{-6} \mathrm{~mol} \cdot \mathrm{I}^{-1} ; \mathrm{C}_{\mathrm{TpOOOI}}=5.4 \cdot 10^{-5} \mathrm{~mol} \cdot \mathrm{I}^{-1}\right.$; $\left.\mathrm{C}\left(\mathrm{Na}_{2} \mathrm{~B}_{4} \mathrm{O}_{7}\right)=0.05 \mathrm{~mol} \cdot \mathrm{l}^{-1} ; \mathrm{pH}=8.0 ; \lambda=364 \mathrm{~nm} ; l=3 \mathrm{~cm}\right)$ using masking agents

\begin{tabular}{|c|c|c|c|c|}
\hline \multirow{2}{*}{ Extraneous ions } & \multicolumn{4}{|c|}{ Masking agent $\left(\mathrm{C}_{\text {Os }}: \mathrm{C}_{\text {Ion }}: \mathrm{C}_{\text {Masking agent }}\right)$} \\
\cline { 2 - 5 } & EDTA & Cit $^{3-}$ & art $^{-2}$ & $\mathrm{~F}^{-}$ \\
\hline $\mathrm{Fe}(\mathrm{III})$ & - & $1: 5: 80$ & - & - \\
\hline $\mathrm{Al}(\mathrm{III})$ & $1: 50: 20$ & $1: 50: 80$ & $1: 20: 20$ & $1: 10: 500$ \\
\hline $\mathrm{Pb}(\mathrm{II})$ & $1: 5: 20$ & - & - & - \\
\hline $\mathrm{Zn}(\mathrm{II})$ & $1: 20: 20$ & $1: 10: 80$ & - & - \\
\hline $\mathrm{Ni}(\mathrm{II})$ & $1: 10: 20$ & $1: 2: 80$ & $1: 10: 20$ & $1: 2: 500$ \\
\hline $\mathrm{Cu}(\mathrm{II})$ & $1: 5: 20$ & $1: 5: 80$ & $1: 20: 20$ & - \\
\hline $\mathrm{Au}(\mathrm{III})$ & - & $1: 3: 80$ & - & - \\
\hline $\mathrm{Ce}(\mathrm{IV})$ & $1: 1.5: 20$ & - & - & - \\
\hline $\mathrm{Ce}(\mathrm{III})$ & $1: 5: 20$ & - & - & - \\
\hline $\mathrm{Gd}(\mathrm{III})$ & $1: 5: 20$ & - & $1: 2: 20$ & $1: 5: 500$ \\
\hline $\mathrm{Eu}(\mathrm{III})$ & $1: 20: 20$ & - & $1: 10: 20$ & $1: 10: 500$ \\
\hline $\mathrm{Ru}(\mathrm{IV})$ & $1: 10 *: 20$ & $1: 10 *: 80$ & - & - \\
\hline $\mathrm{Rh}(\mathrm{III})$ & $1: 15: 20$ & $1: 5: 80$ & $1: 5: 20$ & $1: 5: 500$ \\
\hline $\mathrm{Pt}(\mathrm{IV})$ & $1: 5: 20$ & $1: 10 *: 80$ & - & $1: 5: 500$ \\
\hline $\mathrm{Ir}(\mathrm{IV})$ & $1: 10 *: 20$ & $1: 8: 80$ & $1: 7: 20$ & $1: 5: 500$ \\
\hline
\end{tabular}

* higher concentrations of marked ions were not investigated;

— no masking effect detected

extraneous ions, particularly concomitant ions of PGEs and other metals as well as the ions, which may be brought in during the samples treatment by the spectrophotometric determination of osmium with Tropaeolin $\mathrm{O}$ or Tropaeolin OOO-I in various complex samples. The most effective masking reagent appeared to be EDTA, which does not form complexes with osmium [1], but it is able to form stable complex compounds with many metals ions, including other PGEs. Other masking agents also appeared to be efficient, especially the anions of organic acids.

\subsection{Application of the Methods to Determination of Osmium in Model Solutions}

The accuracy of these methods for determination of Os(IV) with Tropaeolin O and Tropaeolin OOO-I has 
Table 6

Accuracy of the spectrophotometric determination of osmium (IV) in model solutions by means of Tropaeolin $\mathrm{O}\left(\mathrm{C}_{\mathrm{TpO}}=1.2 \cdot 10^{-4} \mathrm{~mol} \cdot \mathrm{l}^{-1} ; \mathrm{C}\left(\mathrm{CH}_{3} \mathrm{COONa}+\mathrm{CH}_{3} \mathrm{COOH}\right)=0.3 \mathrm{~mol} \cdot \mathrm{l}^{-1} ; \mathrm{pH}=5.2 ; \lambda=540 \mathrm{~nm}\right.$; $l=5 \mathrm{~cm})$ and Tropaeolin OOO-I $\left(\mathrm{C}_{\mathrm{TpOOOI}}=5.4 \cdot 10^{-5} \mathrm{~mol} \cdot \mathrm{l}^{-1} ; \mathrm{C}\left(\mathrm{Na}_{2} \mathrm{~B}_{4} \mathrm{O}_{7}\right)=0.05 \mathrm{~mol} \cdot \mathrm{l}^{-1} ; \mathrm{pH}=8.0\right.$; $\lambda=364 \mathrm{~nm} ; \mathrm{l}=3 \mathrm{~cm}) . n=5 ; P=0.95$

\begin{tabular}{|c|c|c|c|c|c|}
\hline Reagent & System & $\mathrm{C}_{\mathrm{O}}: \mathrm{C}_{\text {Ion }}: \mathrm{C}_{\text {Masking agent }}$ & $\begin{array}{c}\text { Added } \\
\text { osmium, } \mu \mathrm{g}\end{array}$ & $\begin{array}{l}\text { Found osmium, } \\
\bar{x} \pm \frac{S \times t_{\alpha}}{\sqrt{n}}, \mu \mathrm{g}\end{array}$ & $\mathrm{RSD}, \%$ \\
\hline \multirow{5}{*}{$\mathrm{TpO}$} & Os(IV)-Rh(III)-EDTA & $1: 2: 30$ & \multirow{5}{*}{215.0} & $223.4 \pm 9.2$ & 3.3 \\
\hline & Os(IV)-Pd(II)-EDTA & $1: 1: 30$ & & $207.6 \pm 10.4$ & 4.1 \\
\hline & Os(IV)-Pt(IV)-EDTA & $1: 5: 30$ & & $208.5 \pm 8.6$ & 3.4 \\
\hline & Os(IV)-Ir(IV)-EDTA & $1: 4: 30$ & & $221.1 \pm 7.0$ & 2.6 \\
\hline & Os(IV)-Ru(IV)-Tart ${ }^{2-}$ & $1: 2: 40$ & & $224.5 \pm 9.6$ & 3.5 \\
\hline \multirow{6}{*}{ TpOOOI } & Os(IV)-Rh(III)-EDTA & $1: 10: 20$ & \multirow{6}{*}{21.7} & $22.5 \pm 1.0$ & 3.6 \\
\hline & Os(IV)-Ru(IV)-EDTA & $1: 10: 20$ & & $22.0 \pm 0.4$ & 1.5 \\
\hline & Os(IV)-Ir(IV)-EDTA & 1:10:20 & & $21.4 \pm 0.9$ & 3.4 \\
\hline & Os(IV)-Ru(IV)-Cit ${ }^{3-}$ & $1: 10: 80$ & & $22.2 \pm 0.7$ & 2.6 \\
\hline & $\mathrm{Os}(\mathrm{IV})-\mathrm{Pt}(\mathrm{IV})-\mathrm{Cit}^{3-}$ & $1: 10: 80$ & & $22.2 \pm 0.6$ & 2.2 \\
\hline & Os(IV)-Pd(II) & $1: 5$ & & $22.1 \pm 0.5$ & 1.8 \\
\hline
\end{tabular}

Results of the spectrophotometric determination of osmium in the intermetallide $\mathbf{N d}_{20} \mathrm{Os}_{15} \mathrm{Si}_{65}$ with Tropaeolin $\mathrm{O}\left(\mathrm{C}_{\mathrm{TpO}}=\mathbf{1 . 2 \cdot 1 0 ^ { - 4 }} \mathrm{mol} \cdot \mathrm{I}^{-1} ; \mathrm{C}\left(\mathrm{CH}_{3} \mathrm{COONa}+\mathrm{CH}_{3} \mathrm{COOH}\right)=0.3 \mathrm{~mol} \cdot \mathrm{l}^{-1} ; \mathbf{p H}=\mathbf{5 . 2}\right.$; $\lambda=540 \mathrm{~nm} ; l=5 \mathrm{~cm})$ and Tropaeolin OOO-I $\left(\mathrm{C}_{\mathrm{TpOoOI}}=5.4 \cdot 10^{-5} \mathrm{~mol} \cdot \mathrm{l}^{-1} ; \mathrm{C}\left(\mathrm{Na}_{2} \mathrm{~B}_{4} \mathrm{O}_{7}\right)=0.05 \mathrm{~mol} \cdot \mathrm{l}^{-1}\right.$; $\mathrm{pH}=8.0 ; \lambda=364 \mathrm{~nm} ; l=3 \mathrm{~cm}) . n=5 ; P=0.95$

\begin{tabular}{|c|c|c|c|c|c|}
\hline \multirow{2}{*}{ Reagent } & \multirow{2}{*}{$\omega_{O s}^{\text {calc. }}, \%$} & $C_{O S}^{c a l c .}, \mu \mathrm{g} \mathrm{ml}{ }^{-1}$ & $\bar{C}_{O s}^{p r}, \mu \mathrm{g} \mathrm{ml}^{-1}$ & $\bar{\omega}_{O s}^{p r} \pm \frac{S \times t_{\alpha}}{\sqrt{n}}, \%$ & $\mathrm{RSD}, \%$ \\
\cline { 1 - 4 } & \multirow{2}{*}{37.7} & \multirow{2}{*}{86.8} & 87.9 & $38.2 \pm 0.8$ & 1.7 \\
\cline { 1 - 4 } & & 88.0 & $38.3 \pm 0.7$ & 1.5 \\
\hline
\end{tabular}

been tested during the analysis of model solutions using the method "added-found". As it is known, the main problem of the photometric methods for osmium determination is their insufficient selectivity relative to the rest of platinum group elements. Therefore the ions of different noble metals and masking agents such as EDTA, sodium tartrate and citrate, were brought in to the model solutions. Osmium content in the examined solutions was calculated applying the calibration curve method in the presence of the proper masking agent. The results are presented in Table 6.

As it follows from the obtained results, contaminant ions of PGEs present in the solutions practically do not affect the results of analyses if the masking reagents are used. The obtained results correlate well with the amount of osmium added into the model solutions, and the values of RSDs are within the range of ones for photometry. Thus the elaborated methods of osmium determination by means of TpO and TpOOOI can be effectively applied for the analyses of complex industrial and natural samples containing considerable excesses of PGEs relative to osmium.

It is generally known that the procedure of osmium separation in the form of the volatile tetraoxide is very often utilized when the complex multicomponent samples are to be analyzed. However, mostly this process is accompanied by smaller or greater losses of osmium caused by the leakage of the distillation apparatus. In many cases the extraction of osmium compounds as well as noble metals by means of various organic solvents is used to eliminate the interfering influence of the matrices elements. Both these techniques are time- and labourconsuming, and in addition may also result in osmium loss, which anyway in most samples is found in very small quantities. Therefore masking by means of the organic acids anions, applied for the elimination of PGEs during the spectrophotometric determination of osmium with Tropaeolin O and Tropaeolin OOO-I, appeared to be 
an effective alternative to separation of osmium and matrix of the samples, and provided the accuracy of the obtained results of analyses.

\subsection{Methods Approbation during the Analysis of the Alloy}

On the basis of the developed spectrophotometric methods of osmium (IV) determination with the examined azo dyes, osmium content was defined in the real complex sample, viz. in the tri-component intermetallic alloy $\mathrm{Nd}_{20} \mathrm{Os}_{15} \mathrm{Si}_{65}$. According to the results of the selectivity examination of the elaborated methods (Table 3 ) the great amounts of $\mathrm{Nd}(\mathrm{III})$, namely 100 - and 40 -fold relative to Os in case of $\mathrm{TpO}$ and TpOOOI respectively, and 100fold excess of $\mathrm{SiO}_{3}^{2-}$ in case of both azo reagents did not interfere determination of osmium. Since in the intermetallide sample the ratios of neodymium and silicium to osmium are considerably smaller, then the alloy was analyzed directly after dissolution, without using any masking agents.

The procedure of the intermetallide sample dissolution was as follows: $0.01-0.02 \mathrm{~g}$ of the intermetallic alloy was dissolved in $10-20 \mathrm{ml}$ of a mixture of concentrated $\mathrm{HCl}$ and $\mathrm{HNO}_{3}(10: 1)$. The obtained mixture was boiled in a beaker on the sand bath during 1-2 $\mathrm{h}$. Under these conditions the residue of grey colour (metallic silicium) has been observed on the bottom of the beaker. After quantitative transfer of the acidic solution into a $100.0 \mathrm{ml}$ volumetric flask the residue has been dissolved in the small volume of $1 \mathrm{~mol} \cdot \mathrm{l}^{-1}$ sodium hydroxide solution. The obtained alkaline solution has been quantitatively transferred into the same volumetric flask and concentrated $\mathrm{HCl}$ was added to $\mathrm{pH} \leq 1$. Then distilled water was added to the volume of $100.0 \mathrm{ml}$.

For the analytical procedure the $0.5-2.0 \mathrm{ml}$ of analytes aliquots have been taken. Osmium content was evaluated using the methods of standard additions by means of the proper analytical procedure of determination. The results are represented in Table 7.

As it follows from the data of Table 7, the obtained findings correlate well with the nominal osmium content, i.e. calculated in the accordance with atomic per cents in the alloys. The value of relative standard deviations did not exceed the typical values for RSDs in the spectrophotometric analyses.

\section{Conclusions}

The selectivity of the spectrophotometric methods of Os(IV) determination with Tropaeolin $\mathrm{O}$ and Tropaeolin OOO-I relative to foreign metals, including PGEs, has been studied. The selectivity of TpOOOI interaction with osmium (IV) ions in the presence of noble metals is sufficiently higher than the one of TpO. It has been established that the influence of interfering ions can be effectively eliminated by means of typical masking agents. The elaborated methods may be used for the direct evaluation of osmium in complex samples without any preliminary separation of osmium or matrix elements. The accuracy of the methods was tested using the "addedfound" method during the analyses of various model solutions containing PGEs and masking agents. Also osmium content was determined in the intermetallide $\mathrm{Nd}_{20} \mathrm{Os}_{15} \mathrm{Si}_{65}$.

\section{References}

[1] Ginzburg S., Yezerskaya N., Prokofyeva I. et al.: Analiticheskaya Khimiya Platinovyh Metallov. Nauka, Moskwa 1972.

[2] Zolotov Yu., Varshal G. and Ivanov V. (Eds.): Analiticheskaya Khimiya Metallov Platinivoy Gruppy. Collected articles, Moskwa 2003.

[3] Van Loon J. and Barefoot R.: Determination of the Precious Metals. Selected Instrumental Methods. Wiley, Chichester 1991.

[4] Barefoot R. and Van Loon J.: Talanta, 1999., 49, 1.

[5] Hartley F. (Ed.): Chemistry of the Platinum Group Metals. Recent Developments. Elsevier, Amsterdam 1991.

[6] Lazarev N. and Gadaskina I. (Eds.): Vrednyje Veshchestva v Promyshlennosti. Spravochnik dlya Khimikov, Inzhenerov i Vrachey. T. III. Khimiya, Leningrad 1977.

[7] Rao C. and Reddi G.: Trends in Analytic. Chem., 2000, 19, 565.

[8] Qu B.: Analyst, 1996, 121, 139.

[9] Radushev A. and Akkermann G.: Zav. Lab., 1978, 12, 1431.

[10] Bonishko O.: PhD thesis, Lviv 2008.

[11] Beamish F.: Analiticheskaya Knimiya Blagorodnyh Metallov. Mir, Moskwa 1969.

[12] Kholtsbekher Z., Divish L., Kral M. I. et al.: [in:] Vysotsky Z. (Ed.), Organicheskiye Reagenty v Neorganicheskom Analizye. Mir, Moskwa 1979.

[13] Bonishko O., Polko M., Korkuna O. and Vrublevska T.: Visnyk Kharkiv Univ. Ser Khim., 2007, 15, 70.

[14] Polko M., Vrublevska T., Korkuna O. and Boyko M.: Visnyk Lviv Univ. Ser. Khim., 2008, 49, 144.

[15] Bishop E.: Indikatory. T. 1. Mir, Moskwa 1976.

[16] Tsollinger G.: Khimiya Azokrasiteley. Goskhimizdat, Moskwa 1960.

[17] Chernova R., Petrova I. and Guryev K.: Zh. Org. Khim., 1973, 44, 2753 .

[18] Saxena K. and Dey A.: Anal. Chem., 1968, 40, 1280.

[19] Seth R. and Dey A.: J. Indian Chem. Soc, 1963, 40, 794.

[20] Sastry C., Srinivas Y. and Subba Rao P.: Talanta, 1997, 44, 517.

[21] Sastry C., Rao K. and Prasad D.: Talanta, 1995, 42, 311.

[22] Sastry C., Rao K. and Prasad D.: Microchim. Acta, 1996, 122, 53.

[23] Srinubabu G., Sudha Rani B. and Seshagiri Rao J.: E-J. Chem., 2006, 3, 9 .

[24] Turner A., Clifford A. and Ramachandra Rao C.: Anal. Chem., 1958, 30, 1708. 
[25] Balcerzak M. and Swiecicka E.: Talanta, 1996, 43, 471.

[26] Tymoshuk O.: PhD thesis, Lviv 2002.

[27] Miano R. and Garner C.: Inorg. Chem., 1965, 4, 337.

[28] Alimarin I., Khvostova V. and Kadyrova G.: Zh. Analit. Khim., 1975, 30, 2007.

[29] Bulatov M. and Kalinkin I.: Prakticheskoye Rukovodstvo po Fotometricheskim Metodam Analiza. Khimiya, Leningrad 1986.

\section{МАСКУВАННЯ-ЕФЕКТИВНА АЛЬТЕРНАТИВА ВЦДОКРЕМЛЕННЮ ПРИ ВИЗНАЧЕННІ ОСМІЮЗА ДОПОМОГОЮ АЗОБАРВНИКІВ У СКЛАДНИХ ОБ'ЄКТАХ}

Анотація. Вивчено селективність спектрофотометричних методик визначення мікрограмових кількостей осмію (IV) з кислотними моноазобарвниками тропеоліном $O$ (ТрО) та тропеоліном ООО-I (ТрОООІ) відносно супутніх металів: платинових, важких та рідкісноземельних. Встановлено максимально допустимі концентраційні співвідношення компонентів. Вибірковість взаємодї ТрОООІ йонами осмію (IV) відносно платиноїдів значно вища, ніж ТрО. Встановлено, щзо вплив інородних йонів можна ефективно усунути за допомогою маскуючих агентів, таких як ЕДТА, mартрат, цитрат, пірофосфат чи фторид, i таким чином суттєво підвищчити селективність методик визначення осмію з ТрО та ТрОООІ. Методики апробовано при аналізі модельних розчинів різного складу, щзо містили рутеній, платину, паладій, родій, іридій та маскуючі реагенти. Також вміст осмію було визначено в інтерметалічному сплаві $\mathrm{Nd}_{20} \mathrm{Os}_{15} \mathrm{Si}_{65}$. Похибки визначень не перевищують типових значень для спектрофотометричного аналізу $\left(S_{r}<5 \%\right)$. Показано, шо розроблені методики з різними маскуючими агентами можна використовувати для безпосереднього визначення осмію у складних об'єктах без попереднього відокремлення осмію у формі $\mathrm{OsO}_{4}$ чи екстрагування елементів матриці.

Ключові слова: осмій, спектрофотометричне визначення, тропеолін О, тропеолін ООО-I, селективність, маскування, максимально допустима концентрація стороннього йона. 